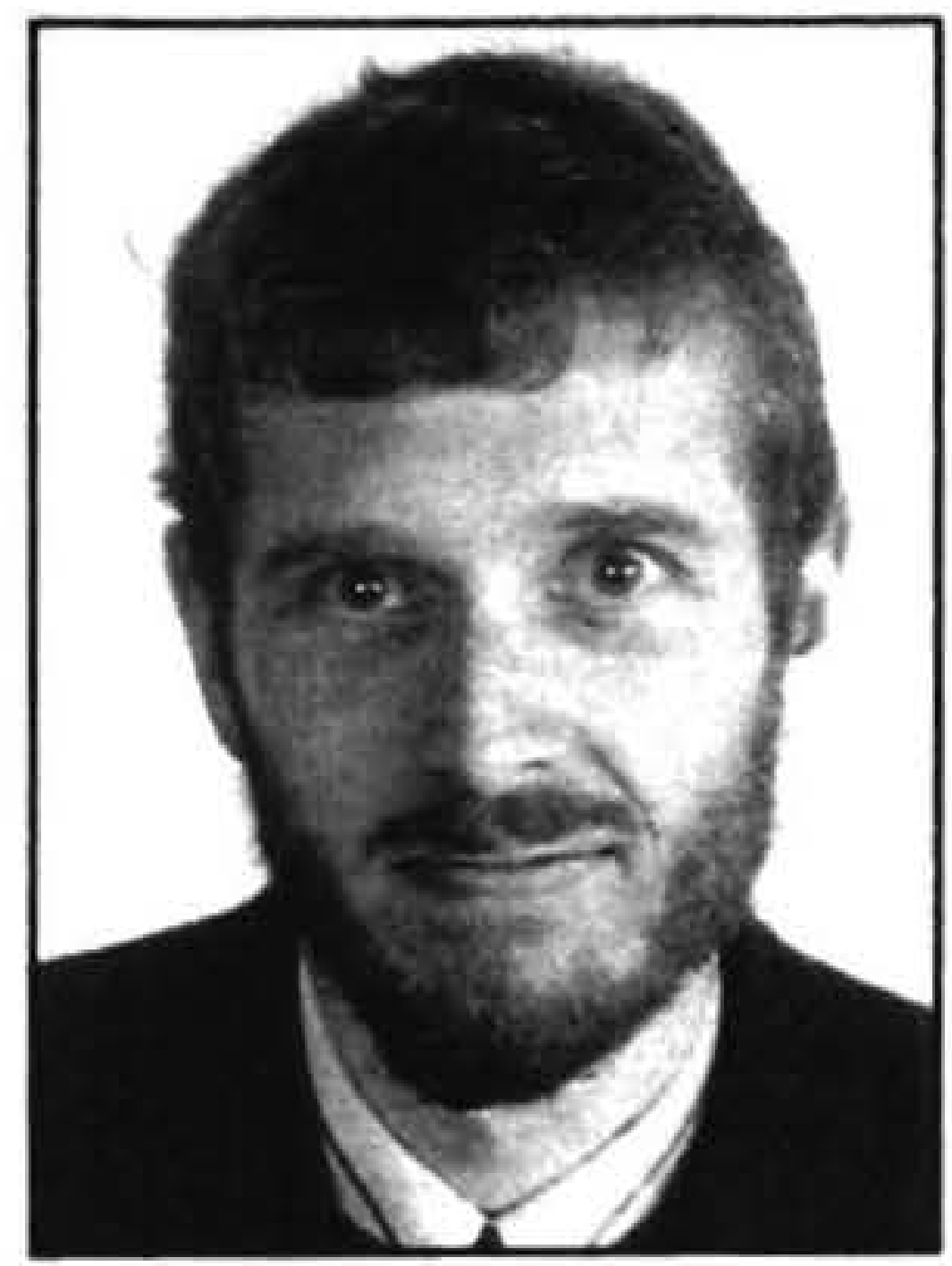

\title{
LABOUR MARKET TRENDS, CYCLES AND OUTLOOK
}

\author{
Dave Maré \\ Labour Market Policy Group \\ Department of Labour
}

\begin{abstract}
This paper outlines recent developments in the labour market, and discusses the likely outlook over coming years. Changes in labour market measures in the past five years have, to varying degrees, been reversals of the changes that occurred in the late 1980s. There are some exceptions to this statement, and differences in the extent of reversal. In this paper we discuss how today's labour market differs from that of the mid-19SOS, which differences will persist, and what commentators forecast for the coming years.
\end{abstract}

No single story can explain the changes that have been observed in the New Zealand labour market over the past ten years. For the researcher and commentator, this makes the study of recent and current trends both fascinating and immensely frustrating. There is a great deal that needs to be controlled for when trying to isolate any particular hypothesised relationship or causal link. To start with, there are long term trends in labour market variables that must be taken into account. Other changes arise from international economic developments, and domestic business-cycles. In New Zealand, there havealso been significant policy changes over the past ten to fifteen years, which have been associated with large changes in economic activity.

The scope and extent of the reforms that have taken place in the New Zealand economy and society are well documented and debated elsewhere. ${ }^{1}$ Because the demand for labour is derived from the demand for the goods that it produces, it is hard to think of a single significant reform that has not had some effect on labour market patterns - and the list of reforms is substantial, and includes deflation, trade liberalisation, removal of subsidies, financial deregulation. and public sector reform.

There have also been policy changes that have more directly affected the labour market, including the introduction of the Employment Contracts Act, changes to the benefit system, and a range of active labour market policies.

At a descriptive level, a common pattern in a number of key labour market series is that of at least a partial reversal - the poor labour market performance of the 1985-91 period has been largely reversed between 1991 and 1996 . There are, of course, exceptions to this rather simple characterisation, and it is these exceptions that are the most interesting.

In order to make any meaningful inferences about the significance of observed recent and current labour market changes, it is necessary to consider them in the context of long term trends, international influences, domestic cycles, and the (long-lasting) effects of policy changes. The remainder of this paper discusses recent New Zealand labour market changes in the light of this breadth of influences, and concludes with a discussion of the outlook for the New Zealand labour market.

\section{Two contrasting views}

There has been much debate over the past decade about the nature of labour market changes in New Zealand, the longterm significance of those changes, and the causes of observed patterns. The data are generous, in the sense that, by judicious choice of time period and variables, it is possible to paint quite different pictures of what has happened.

Consider, for example, the following two accounts of the New Zealand labour market - one that shows that the performance of the labour market has been stunning, and one that shows limited evidence of improvement. In the discussion that follows, I hope to show that both interpretations are wrong, because both are only partial accounts.

Stunning performance (1991-96)...

The performance of the New Zealand labour market over the past five years has been nothing less than spectacular. The first column of Table One shows impressive progress for a range of labour market variables.

Employment increased by an average of 2.8 percent per annum, unemployment declined by 4.1 percent per annum, lowering the unemployment rate from 10.7 percent to 6.1 percent, and the proportion of the working age population participating in the labour force rose by an average of 0.4 
Table One. Annualised growth for selected variables

\begin{tabular}{lll}
\hline Variable & $\begin{array}{l}\text { Change } \\
1991-96\end{array}$ & $\begin{array}{l}\text { Change } \\
1986-96\end{array}$ \\
\hline $\begin{array}{l}\text { Output } \\
\text { (Annual percent change) }\end{array}$ & $2.8 \%$ & $1.6 \%$ \\
$\begin{array}{l}\text { Total Employment } \\
\text { (Annual percent change) }\end{array}$ & $2.5 \%$ & $0.9 \%$ \\
$\begin{array}{l}\text { Full-time employment } \\
\text { (Annual percent change) }\end{array}$ & $2.1 \%$ & $0.2 \%$ \\
$\begin{array}{l}\text { Total unemployment } \\
\text { (Annual percent change) }\end{array}$ & $-4.1 \%$ & $7.4 \%$ \\
$\begin{array}{l}\text { Long-term/ Total unemployment } \\
\text { (Annual percentage point change) }\end{array}$ & -0.5 & 1.8 \\
$\begin{array}{l}\text { Participation rate } \\
\text { (Annual percentage point change) }\end{array}$ & 0.4 & -0.1 \\
\hline
\end{tabular}

percentage points per year. The strong employment growth was a result of growth in both full-time and part-time employment. Employment growth was strong in all industry and occupation groups, for all major demographic groups, and for full-time as well as part-time employment. ${ }^{2}$

Similarly, the declines in unemployment rates were experienced by all major demographic groups, and were strongest for those with the highest unemployment rates. Participation rates also rose for all major demographic groups, and there were 2.5 more percent of the working age population participating in the labour market in 1996 than there were in 1991.

\section{... or Slow progress? (1986-96)}

If we consider the longer period of 1986 to $1996^{3}$, we get quite a different picture of the labour market. Looking at the second column of Table One, we see that the annualised growth rates for employment, wages, and participation were all fairly low when we consider the $1986-96$ period as a whole. Similarly, the unemployment rate is in fact still higher today than it was in 1986 , and the participation rate has only just regained its 1986 level.

Although, as discussed under the previous heading, all major demographic groups benefited from the recovery of 199196 , there are still stark differences in the labour market experience of different groups. For instance, the unemployment rate for Maori in September 1996 was 3.1 times as high as that for non-Maori (15.9 percent for Maori, compared with 5.2 for non-Maori). Participation rates are also lower for Maori than for other ethnic groups.

\section{Degrees of reversal}

So how do we resolve these two seemingly conflicting accounts of the New Zealand labour market. Obviously, the difference in time periods is the source of the conflict. In order to understand recent developments in the New Zealand labour market, it is necessary to realise that the 1986-91 period was characterised by worsening labour market out- comes, and stands in sharp contrast with the 1991-96 period, which was characterised by substantial improvements. It is equally misguided to extrapolate from the last five years and infer that recent growth rates represent sustainable long term trends, or to extrapolate from the past ten years, and conclude that we are destined to have permanently low rates of output and employment growth.

The poor output and employment performance of the late 1980 s and the early 1990 s was clearly a deviation from longterm growth trends. The strength of recovery since 1992 shows that these deviations were not permanent. Moreover, the pattern of reversal makes it difficult to identify whether there have heen any structural shifts in the New Zealand economy and labour market. In order to do this, we need to disentangle the effects of the cyclical reversal, longer term trends, structural shifts, and changes that are common across other developed countries. It is not until we have identified some of these effects separately that we can determine whether the reforms and changes that New Zealand has experienced have had a long-term effect on the levels or on the growth rates of economic and labour market variables, compared with pre-1984 performance.

Although the problem of identifying these effects separately is always present, it is particularly frustrating for the analysis of recent New Zealand labour market performance. Even twelve years after the reforms began, it is difficult to make judgements, due to the unusually long cycle, and the likelihood that current changes still reflect some degree of readjustment.

Drawing inferences is made all the more difficult by the fact that not all variables adjust at the same rate. The unemployment rate, for instance, is still above its 1986 level. We should not, however, conclude that there has been a longterm change in the unemployment rate. While we cannot reject that hypothesis, it is possible that unemployment just adjusts more slowly than other variables.

Another complication is that some structural changes were occurring prior to 1984 , and that others may be the result of international forces that are unrelated to New Zealand's reforms. Any comparison of economic and labour market performance or structure between 1984 and today needs to consider these complications.

\section{Output and employment}

Graph ()ne shows the movements in output (from 1977) and employment (from 1986). ${ }^{4}$ Both output and employment show poor performance in the 1986 to 1992 period, and improvement since then. The source of the two conflicting stories about the labour market is clearly evident in Graph One. The more positive story captures only the period of recovery, and the less positive story includes the 1987-93 period of contraction, which lowers the average rate of growth.

Output had been growing since at least 1977, when the series started, until about 1986 , with a brief contraction in 1983 . In 
the years from 1987 to 1992 , the level of output barely increased - the rate of growth ${ }^{5}$ averaged 0.1 percent per annum. This compares with growth of 2.3 percent per annum for the 1978 to 1986 period, and growth of 4.5 percent per annum for 1993 to 1995.

Employment had also been growing prior to 1987, although at a slightly lower rate than output, reflecting growth in average labour productivity. As output growth slowed around 1987, employment started contracting, and by the beginning of 1990 , was about five percent lower than it was in $1986 .{ }^{6}$ By 1993 , both employment and output were again growing, at a faster rate than they were prior to 1987.

The strong growth in employment between 1993 and the present is due both to a reversal of the downturn of the $1980 \mathrm{~s}$, and resumption of trend growth. It is difficult to determine whether sustainable growth rates have been raised by the reforms, as intended, because we cannot separately identify the pace of reversal.

\section{Disaggregated employment changes}

The output and employment series in Graph One reflect changes in economy-wide aggregates. The changes were not, however, uniform across different subgroups. Consequently, the degree of decline, and the degree of recovery varied across sub-groups. Graph Two illustrates the marked differences in changes for full-time and part-time employment between 1986 and 1996. It is clear that the pattern that was observed for total employment in Graph One is due almost entirely to changes in full-time employment. The number of full-time employed workers returned to its 1986 level in the December 1995 quarter, six quarters later than the restoration of 1986 total employment levels. The difference is due to the fact that part-time employment did not experience the same sort of declines that are evident in the full-time track. Part-time employment continued to grow at an average of ahout three to four percent per annum between 1986 and 1996, slowing noticeably only in 1989 and 1993.

Table Two shows employment growth rates for different demographic, industry, and 'hours worked' groupings of employment. The general pattern of negative or slow growth in the 1986-91 period, followed by some degree of reversal in the 1991-96 period is evident for almost all of the subgroups. The differences in pattern across sub-groups are, however, significant.

Some groups experienced much greater declines than aver-

\section{Graph 1. Output and employment levels}

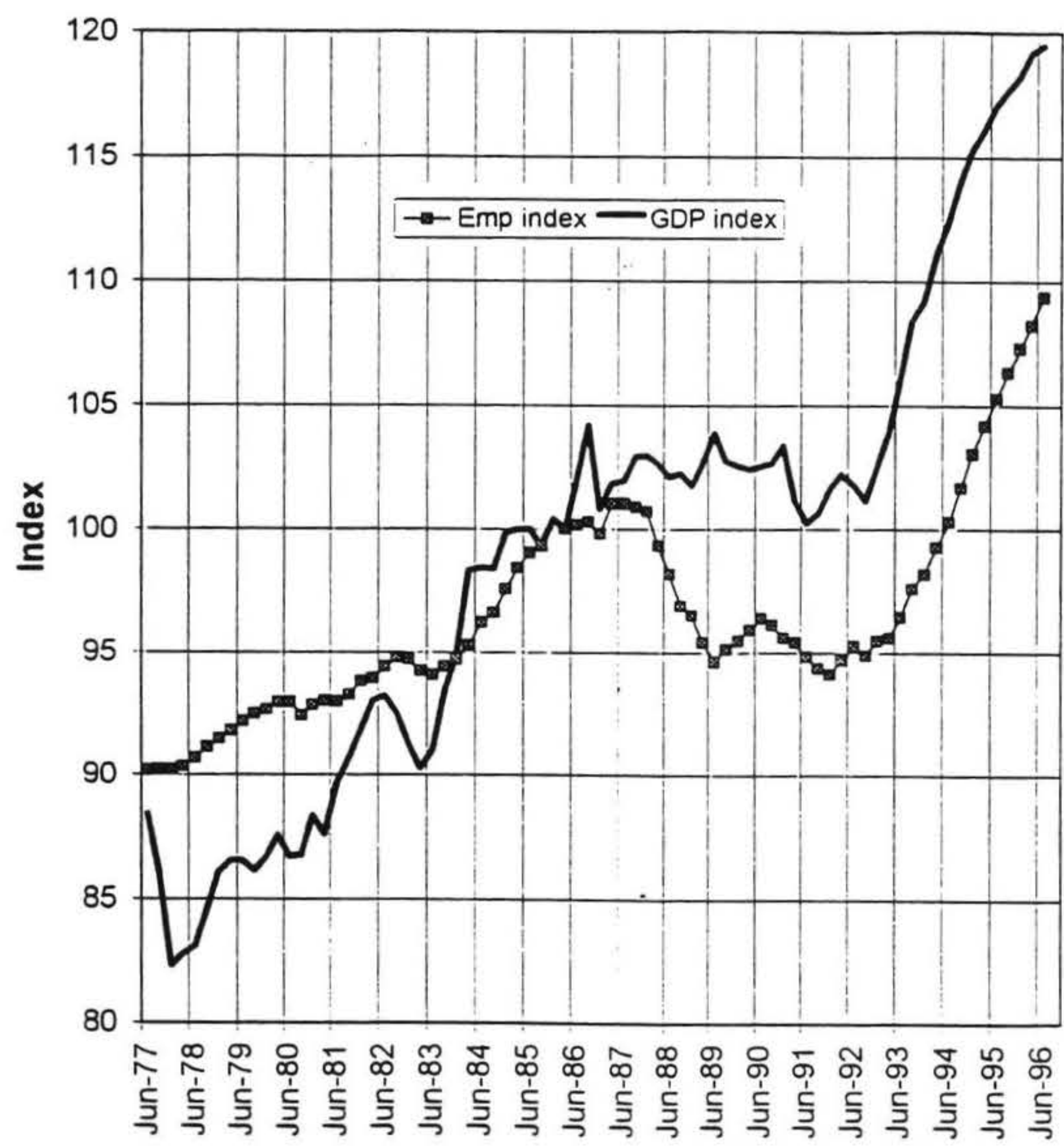

Source: Statistics New Zealand. Employment data from HLFS and backdated HLFS series prepared by NZIER. Output data are seasonally adjusted GDP(Production). Both series have been converted to indexes, with March 1986 set to 100. 
Graph 2. Fulltime and part-time employment changes since 1986

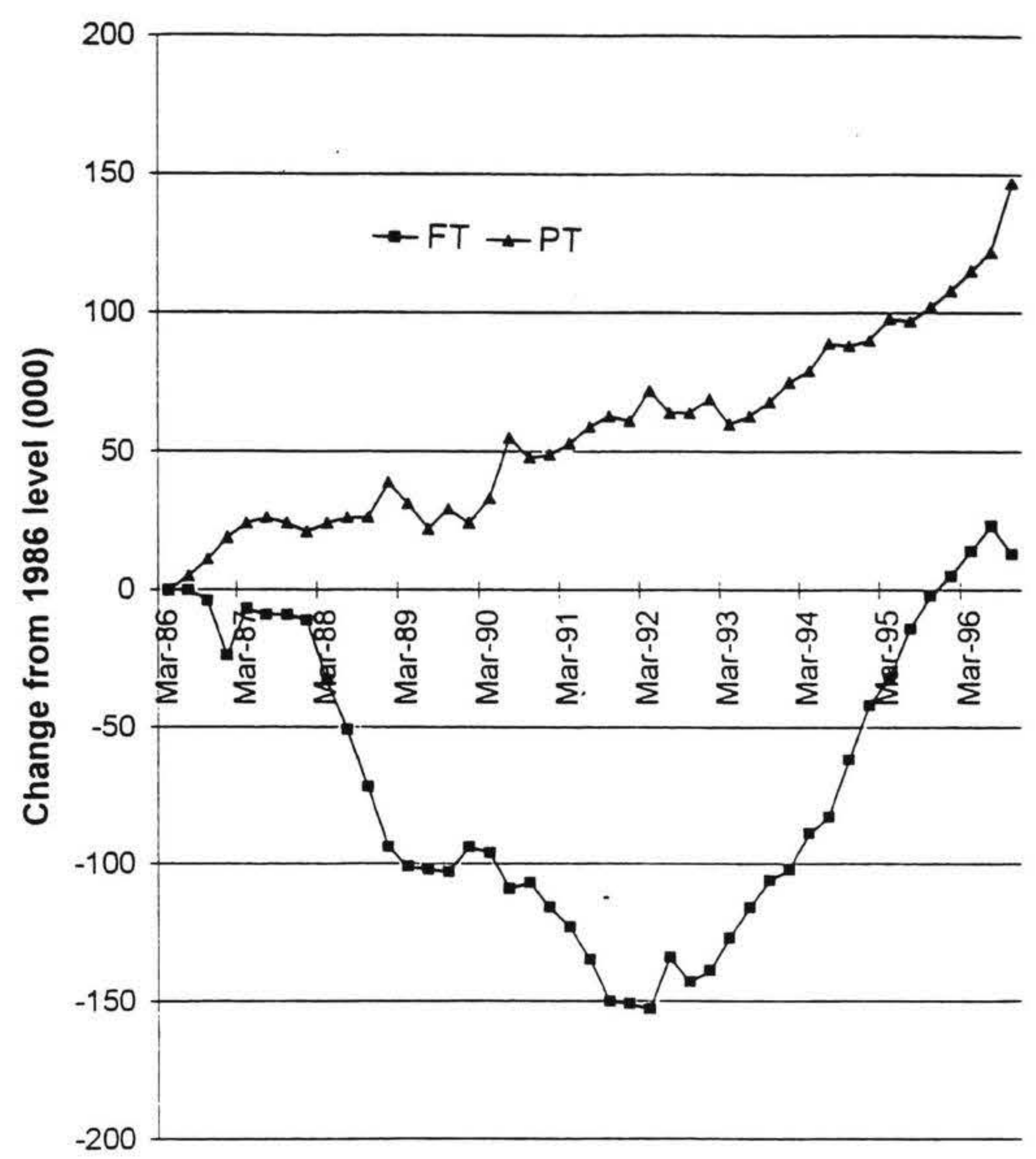

Source: Statistics New Zealand, Household Labour Force Survey, seasonally adjusted series.

age during 1986-91: Maori and Pacific Islands peoples, young people, those with no qualifications, manufacturing industries, and "other" industries. Of these, some also experienced stronger than average growth after 1991, suggesting that they were, for various reasons, more sensitive to the factors that shaped overall employment changes. The cyclically sensitive industries of manufacturing, and "other" (which contains building and construction) fall into this category, as do Maori and Pacific Islands peoples.

Other groups did uniformly better or uniformly worse than average over the period. Groups that had smaller than average declines in 1986-91 and greater than average increases in 1991-96 include those with school or post-school qualifications, part-time workers, and those in Service industries. In contrast, other groups fared worse than average in both periods. Those with no qualifications, and those aged 15-24 years fall into this class, and for both of these groups, employment levels are still below what they were in 1986.

In order to interpret the observed patterns, we would need to consider factors such as demographic changes, changes in the level of educational qualifications, and longer term trends for employment growth in particular industries, or in part-time employment. A discussion along these lines is included in a later section of this paper.

\section{Productivity}

Labour productivity measures the amount of output produced by a given quantity of labour. Rising labour productivity is necessary for sustainable increases in real wages and employment. When productivity rises, it is possible to pay workers more, employ more workers, or both.

One common indicator of labour productivity is "average labour productivity", which measures output per worker or output per hour worked. This is only a rough indicator because it also captures the effects of other determinants of output. With this measure, changes in the amount of other inputs, and changes in technology are all attributed to labour.

In the discussion of Graph One, it was noted that labour productivity was growing whenever output grew faster than employment. In order to examine the changes in labour productivity between 1986 and 1996, it is preferable to measure labour input by the number of hours worked rather than by the number of workers. ${ }^{8}$

Productivity growth generally rises when output rises, and falls when output falls, because output usually fluctuates more than employment does. This relationship is evident in Graph Two, which shows growth rates for output and 


\begin{tabular}{|c|c|c|c|}
\hline & $\begin{array}{l}1986 \text { - } 1991 \\
\text { September qtrs } \\
\text { percentage change }\end{array}$ & $\begin{array}{l}1991-1996 \\
\text { September qtrs } \\
\text { percentage change }\end{array}$ & $\begin{array}{l}1986-1996 \\
\text { September qtrs } \\
\text { percentage change }\end{array}$ \\
\hline Aggregate Employment & $-5.9 \%$ & $17.2 \%$ & $10.3 \%$ \\
\hline Full-time & $-11.4 \%$ & $14.3 \%$ & $1.3 \%$ \\
\hline Part-time & $20.8 \%$ & $27.5 \%$ & $54.1 \%$ \\
\hline Male & $-10.0 \%$ & $15.6 \%$ & $4.0 \%$ \\
\hline Female & $0.1 \%$ & $19.3 \%$ & $19.1 \%$ \\
\hline Pakeha & $-3.1 \%$ & $15.4 \%$ & $11.9 \%$ \\
\hline Maori & $-18.7 \%$ & $23.2 \%$ & $0.2 \%$ \\
\hline Pacific Islands Peoples ${ }^{7}$ & $-17.4 \%$ & $.59 .3 \%$ & $31.6 \%$ \\
\hline Age $15-19$ & $-27.1 \%$ & $11.4 \%$ & $-18.8 \%$ \\
\hline Age 20-24 & $-19.4 \%$ & $12.4 \%$ & $-9.5 \%$ \\
\hline Age $25-29$ & $-7.4 \%$ & $9.7 \%$ & $1.6 \%$ \\
\hline Age $30-54$ & $5.4 \%$ & $17.9 \%$ & $24.3 \%$ \\
\hline Age $55-59$ & $-14.0 \%$ & $28.2 \%$ & $-10.3 \%$ \\
\hline Age $60+$ & $-29.5 \%$ & $40.9 \%$ & $-0.7 \%$ \\
\hline No qualifications & $-28.7 \%$ & $-2.0 \%$ & $-30.1 \%$ \\
\hline School qualifications & $5.5 \%$ & $27.6 \%$ & $34.6 \%$ \\
\hline Post-school qualifications & $6.0 \%$ & $22.0 \%$ & $29.3 \%$ \\
\hline Primary Industries & $-2.3 \%$ & $-1.1 \%$ & $-3.4 \%$ \\
\hline Manufacturing Industries & $-20.2 \%$ & $15.0 \%$ & $-8.2 \%$ \\
\hline Service Industries & $0.8 \%$ & $17.9 \%$ & $18.9 \%$ \\
\hline Other industries & $-26.7 \%$ & $48.6 \%$ & $8.9 \%$ \\
\hline
\end{tabular}

Source: Statistics New Zealand. Household Labour Force Survey.

productivity (measured as output per hour) from 1979 to the present. The "flattening out" of the output line that was seen in Graph One shows up here as growth rates that are close to) zero between 1987 and 1993 .

The remarkable feature of the productivity data in Graph Three is that the relationship between output and productivity growth seems to be broken in the 1988 to 1991 period. Productivity grew strongly at a time when output growth was close to zero. This one-off rise in output per hour was followed by relatively weak productivity growth (but strong employment growth) in the 1991 to 1996 period. Until the current "catch-up" of output and employment levels or growth rates is complete, it is hard to tell whether the reforms and restructuring of the 1980 s have led to a higher productivity growth rate or just the one-off increase in productivity levels that we have already seen. This question is an important one for the medium term outlook, and is discussed later in the paper in this context.

\section{Unemployment}

The pattem of unemployment changes over the 1986 to 1996 period mirrors that of employment and output. Just as employment declined through to 1991 and then grew again, so unemployment rose, and then fell. Graph Four shows the sizcahle rise in the unemployment rate from 3.8 percent in September 1986, to 10.7 percent in September 1991. It also shows the subsequent decline, to 6.1 percent in the Septemher 1996 quarter. The other feature of unemployment rate changes that is illustrated is that unemployment rates for some groups followed the same general timing of increases and declines, but with higher initial unemployment rates, and steeper increases and declines. The two groups shown on the graph to illustrate this general pattern are Maori and teenage workers.

For each of the groups listed in Table Three, unemployment rates rose between 1986 and 1991 , and fell between 1991 and 1996. Another common pattern is that unemployment rates in 1996 were higher than those in 1986 for all the groups listed.

There appears to be a great deal of persistence in relative unemployment rates for different groups. The groups that faced the highest unemployment rates in 1986 were the ones that experienced the greatest increases in unemployment rates between 1986 and 1991 . These same groups subsequently experienced the largest declines, but continue to face the highest unemployment rates. Moreover, unemploy- 
Graph 3. Growth in real output and productivity

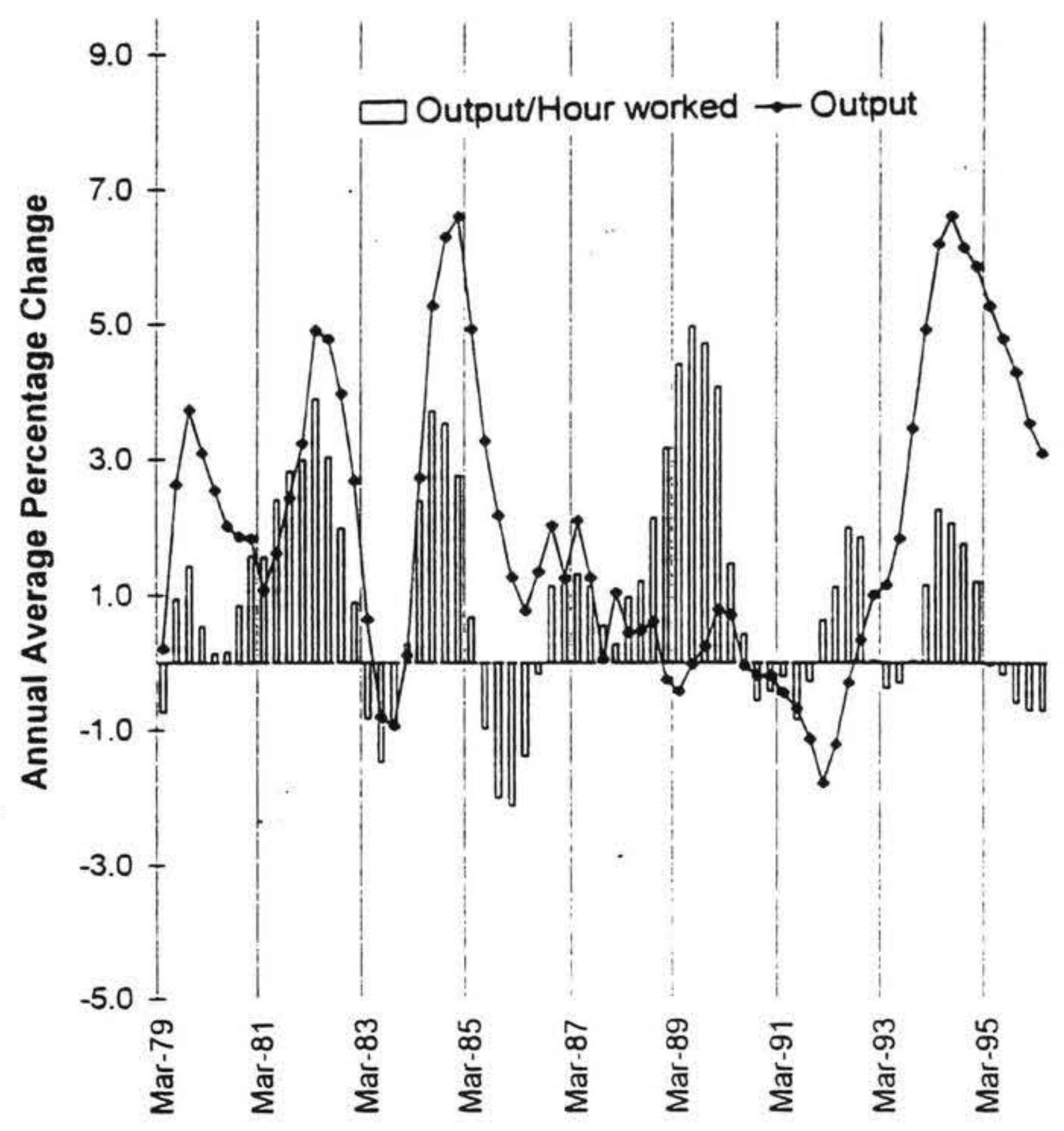

Source: Statistics New Zealand. Output data are GDP(production). Hours data are from the Quarterly Survey of Employment and, prior to 1980, the Half-yearly Survey of Employment.

\section{Graph 4. Unemployment rates}

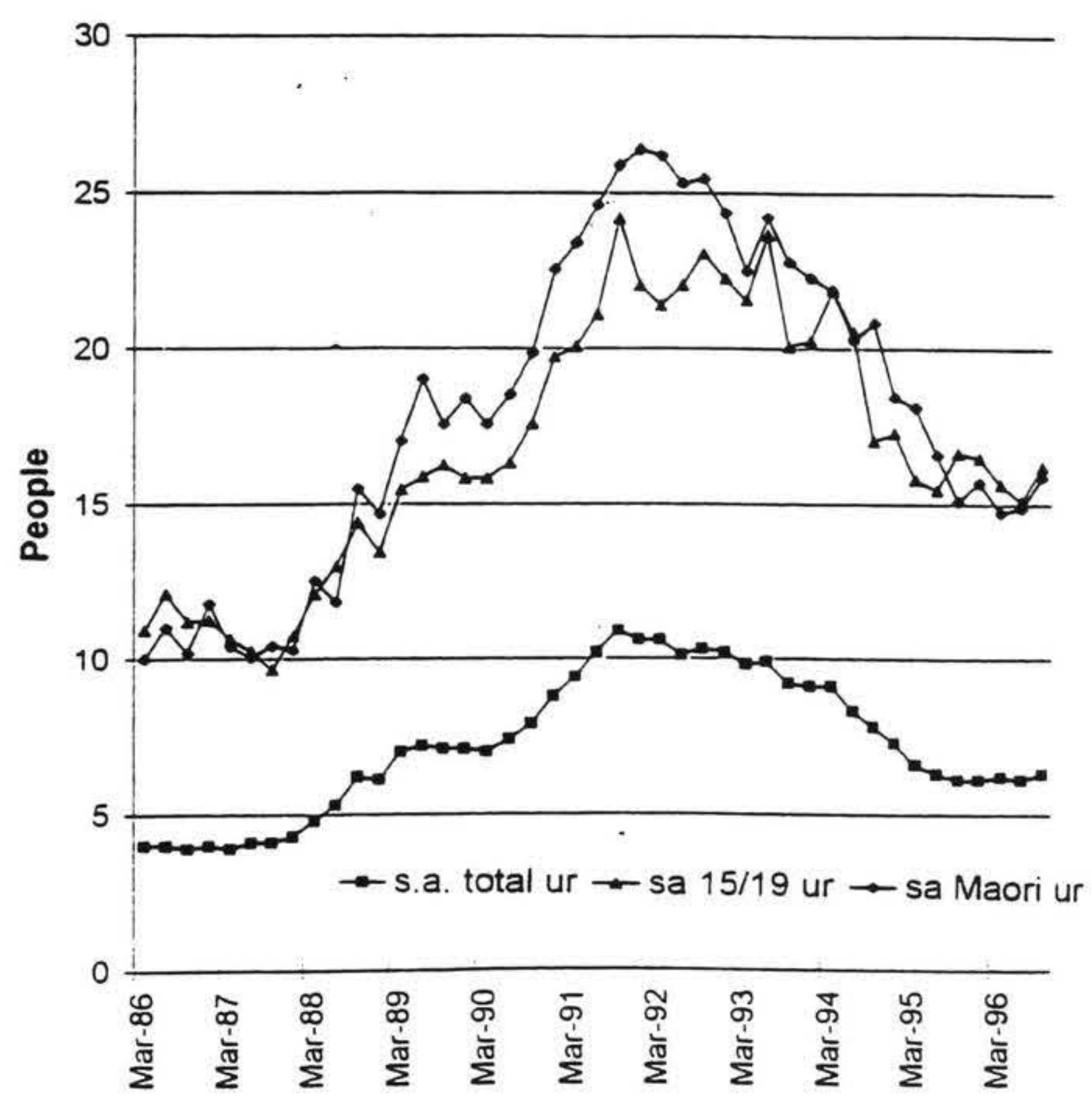

Source: Statistics New Zealand. Household Labour Force Survey. 
ment rates are still higher than they were in 1986 for all groups.

\section{Long-term unemployment}

As unemployment increased, the proportion of those unemployed who had been unemployed for more than six months also increased. This increase in long term unemployment was referred to by the Prime Ministerial Task Force on Employment (ETF) as "perhaps the single most worrying feature of unemployment". 10

Generally, the longer someone has been unemployed, the lower are their chances of leaving unemployment. The ETF were particularly concerned that, when employment growth resumed, those who had been unemployed for a long time would still find it hard to find employment, and that longterm unemployment would account for a growing proposition of unemployment. This appeared to have been the experience of European countries in the late 1980s and early 1990 s.

As shown in Graph Five, from September 1992, the proportion of unemployed persons who were long-term unemployed did decline as the overall unemployment rate declined. At least part of the explanation for this partial reversal is the strong growth in employment for workers with the sorts of characteristics that were over-represented among the long-term unemployed. However, the proportion of unemployed persons who are long term unemployed is still higher today than it was in 1986 (38.2 percent in September 1996, compared with 25.3 percent in September 1986).

\section{Unemployment dynamics}

Administrative data from the Department of Labour's New Zealand Employment Service (NZES) provides us with long-term monthly information on labour market flows that is not available from other sources. ${ }^{11}$ Although the number of jobseekers registered with NZES is not the same as the measure of official unemployment available from the HLFS, the general trends and dynamics of the two measures are similar.

Graph Six shows the changes in annual rates of inflow and outflow for the NZES jobseeker register. Even though the total number of people registered with the NZES as unemployed was rising for almost all of the 1986-1993 period, the pattern of inflows and outflows varied considerably, rising in some periods, and declining in others. The sizeable declines in registered unemployment that have occurred since 1993 have been generated by a slight but steady increase in the number of outflows, and a decline in the number of inflows. It is worrisome that as employment growth has slowed in the past year, inflows have steadily increased, and registered unemployment has started to rise.

\section{Participation rates}

The labour force participation rate measures the proportion of the working age population that is either employed or unemployed. Generally, changes in labour force participation rates are positively related to employment changes, and negatively related to unemployment changes. As the likelihood of gelling a job improves, either because the number of jobs is growing, or because there are fewer unemployed workers searching for jobs, potential jobseekers tend to be

Table 3. Unemployment rates

\begin{tabular}{lrcc}
\hline & $\begin{array}{l}\text { September 1986 } \\
\text { quarter }\end{array}$ & $\begin{array}{l}\text { September 19)1 } \\
\text { quarter }\end{array}$ & $\begin{array}{c}\text { September 1996 } \\
\text { quarter }\end{array}$ \\
\hline Aggregate unemployment rate & $3.8 \%$ & $10.7 \%$ & $6.1 \%$ \\
Male & $3.4 \%$ & $11.5 \%$ & $6.1 \%$ \\
Female & $4.4 \%$ & $9.6 \%$ & $6.1 \%$ \\
Päkehä & $3.1 \%$ & & $4.5 \%$ \\
Mäori & $10.0 \%$ & $8.2 \%$ & $15.9 \%$ \\
Pacific Islands Peoples 9 & $6.6 \%$ & $25.6 \%$ & $14.3 \%$ \\
Age 15-19 & $10.3 \%$ & $30.6 \%$ & $15.2 \%$ \\
Age 20-24 & $4.6 \%$ & $23.0 \%$ & $8.8 \%$ \\
Age 25-29 & $5.1 \%$ & $17.6 \%$ & $7.2 \%$ \\
Age 30-54 & $2.4 \%$ & $12.0 \%$ & $4.4 \%$ \\
Age 55-59 & $1.7 \%$ & $7.7 \%$ & $4.0 \%$ \\
No qualifications & $6.4 \%$ & $6.8 \%$ & $11.1 \%$ \\
School qualifications & $3.3 \%$ & $16.4 \%$ & $5.6 \%$ \\
Post-school qualifications & $1.8 \%$ & $10.1 \%$ & $2.7 \%$ \\
\hline
\end{tabular}

Source: Statistics New Zealand. Household Labour Force Survey. 


\section{Graph 5. Unemployment rates and long term unemployment}

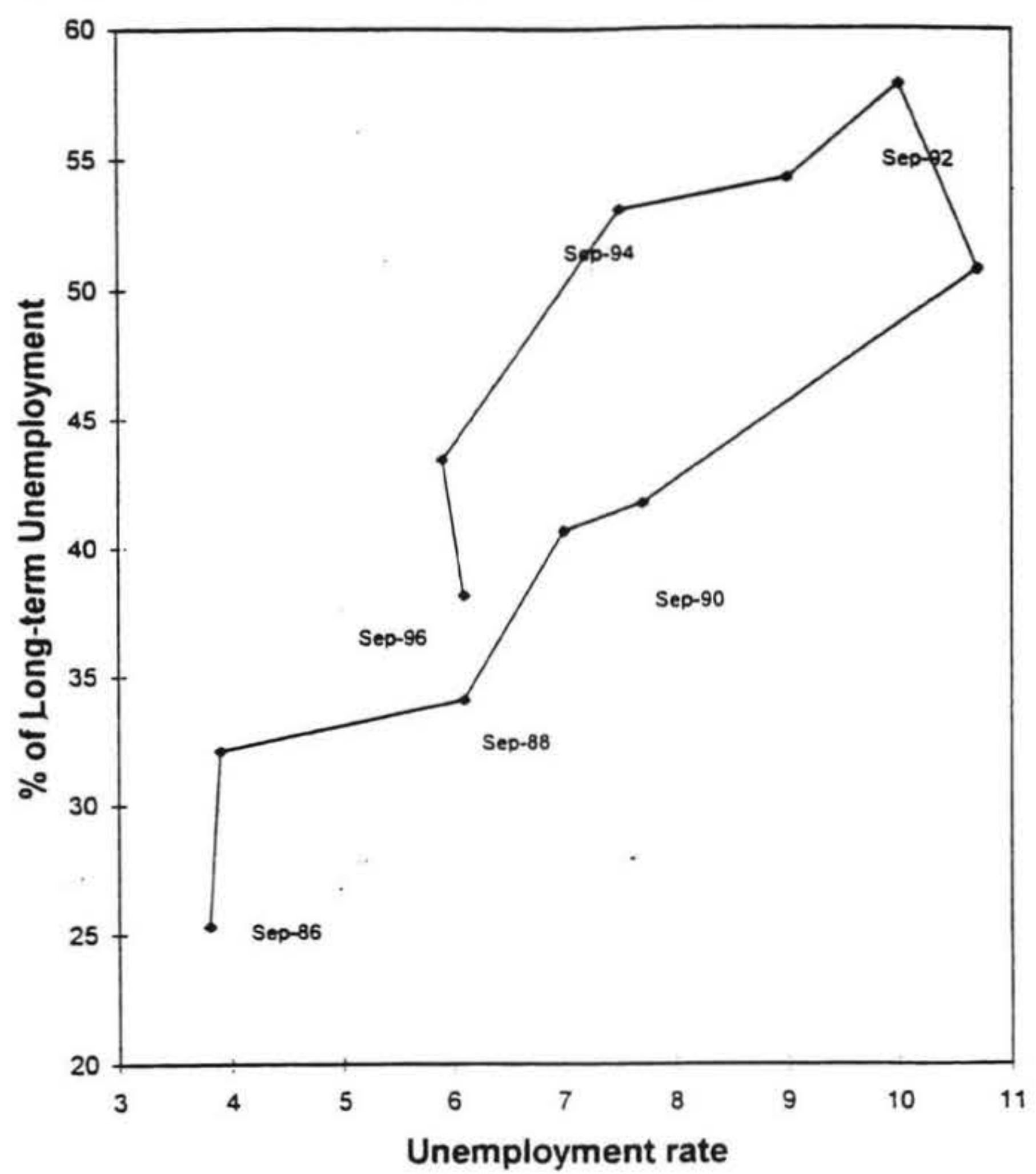

Source: Statistics New Zealand, Household Labour Force Survey.

Graph 6. Registered jobseekers - inflows and outflows

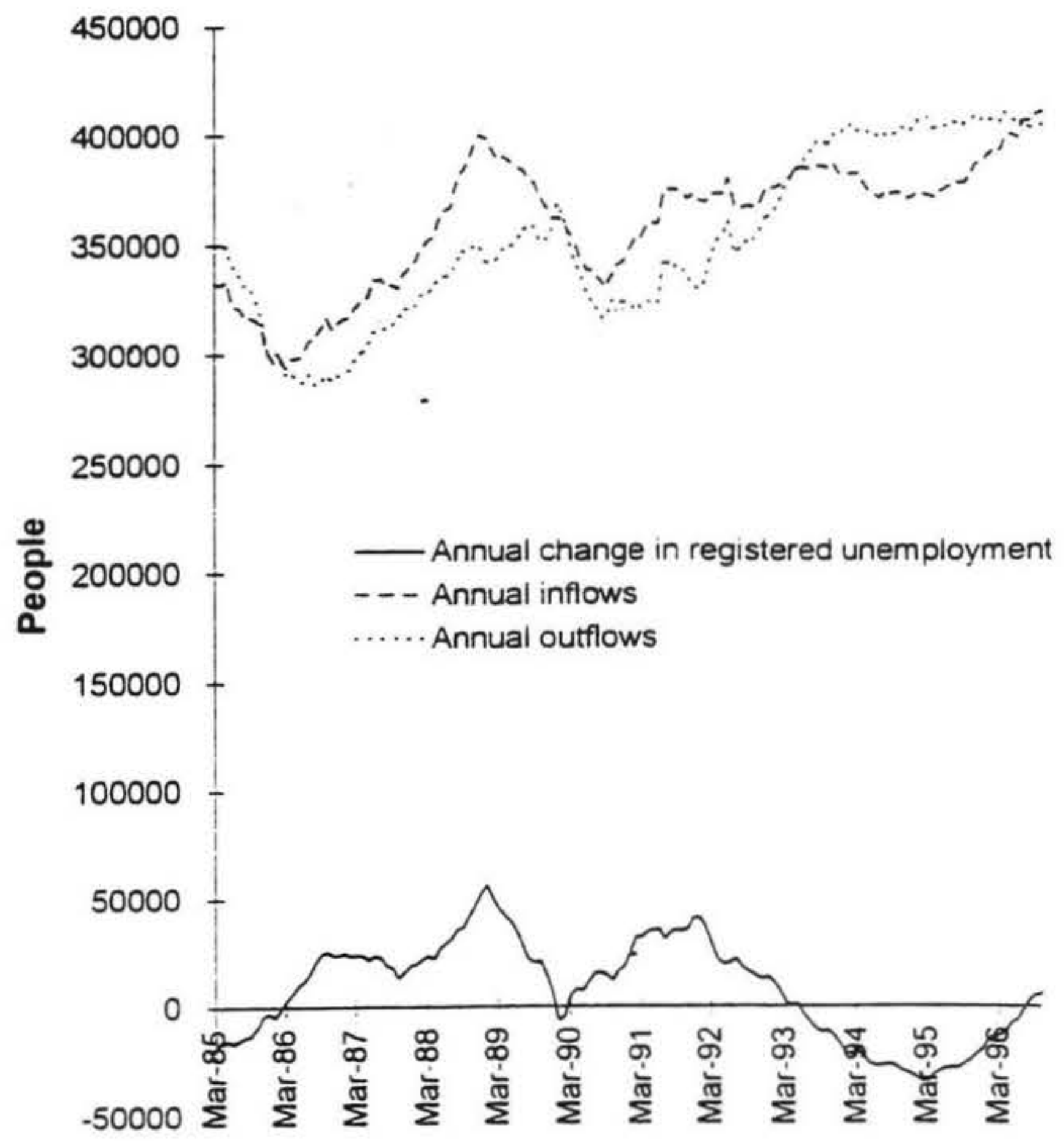

Source: Department of Labour, New Zealand Employment Service .Iobseeker register. Data are registered unemployed jobseekers (excluding vacation workers). 
drawn into the labour force.

It is therefore not surprising that aggregate participation rates fell between 1986 and 1991, and rose between 1993 and 1996. Graph Seven shows the aggregate labour force participation rate, as well as the rates for males, females, and Maori. The participation rate patterns are similar to the patterns for employment. As employment declined, the drop in participation rates would have cushioned the rise in unemployment.

Table Four provides information on participation rate changes for a larger set of subgroups. Females, and those with postschool qualifications were the only groups to experience a rise in participation rates between 1986 and 1991. For females, this reflects a long term trend increase in participation rates that has been occurring for many years.

The table also shows that some groups still have participation rates that are significantly below 1986 levels. Males, Maori, Pacific Islands peoples, 15 to 29 year olds, and those with no qualifications all fall into this group.

\section{Wages}

Wages are somewhat of an exception to the general pattern of decline and regained ground that has been shown to describe other labour market series.
Wage measures are recorded in nominal terms - in the dollars of the day. In order to interpret these measures, it is useful to deflate them by some index of prices. Deflating by a consumer price index yields a wage measure that represents the amount that wage earners can consume from their earnings - the "consumption wage". Deflating by an index of the prices of other inputs yields a measure of the "relative price of labour". Finally, unit labour costs are a measure of the cost of labour that is needed to produce a unit of output. Unit labour costs are affected by changes in productivity as well as price changes.

As shown in Graph Eight, the same general pattern of wage changes is evident for unit labour costs and the labour price measures. ${ }^{13}$ The consumption wage is relatively flat for most of the period, and is still higher currently than it was in 1987 , despite some decline over the past five years. The graph also shows a measure of total hours worked. Unit labour costs and labour prices are the more relevant measures for labour demand, whereas consumption wages are linked more closely to labour supply decisions.

The graph highlights a number of puzzles. The most notable of these is that the strong growth in paid hours over the past three years has occurred at a time when demand-related wage measures were rising sharply. There also appears to be a divergence in the growth rates of consumption wages and demand-related wage measures. Consumption wages have declined slightly, while demand-related measures haverisen.

\section{Graph 7. Participation rates}

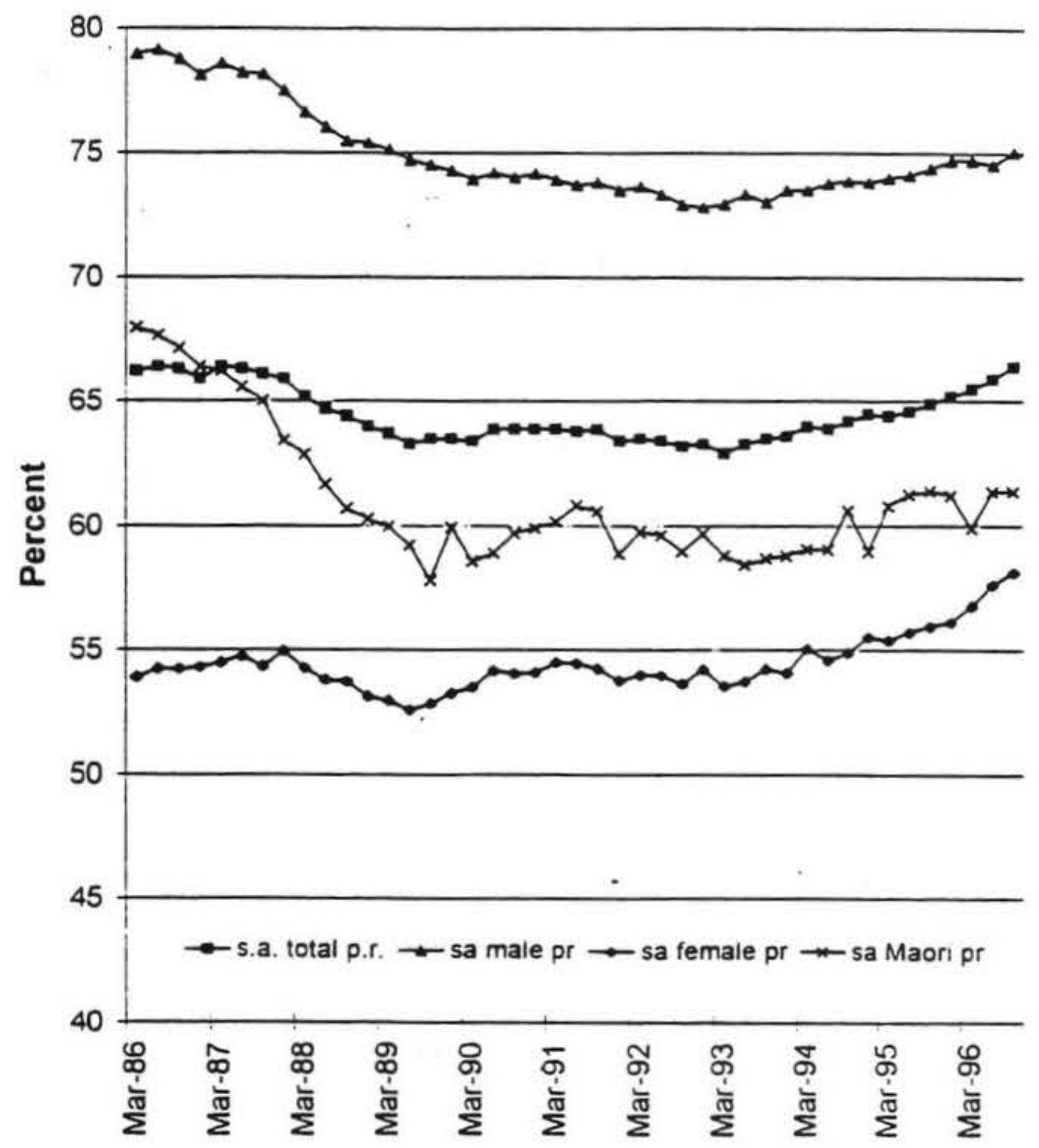

Source: Statistics New Zealand, Household Labour Force Survey. 


\begin{tabular}{llll}
\hline & September 1986 & September 1991 & September 1996 \\
\hline Aggregate participation rate & $65.8 \%$ & $63.3 \%$ & $66.0 \%$ \\
Male & $78.2 \%$ & $73.2 \%$ & $74.5 \%$ \\
Female & $53.9 \%$ & $53.9 \%$ & $57.9 \%$ \\
Päkehä & & & \\
Mäori & $65.5 \%$ & $63.9 \%$ & $67.4 \%$ \\
Pacific Islands Peoples 12 & $66.5 \%$ & $59.8 \%$ & $60.6 \%$ \\
& $69.0 \%$ & $60.4 \%$ & $61.9 \%$ \\
Age 15-19 & & & $56.8 \%$ \\
Age 20-24 & $58.7 \%$ & $53.0 \%$ & $77.5 \%$ \\
Age 25-29 & $81.7 \%$ & $77.3 \%$ & $80.0 \%$ \\
Age 30-54 & $77.4 \%$ & $76.6 \%$ & $83.4 \%$ \\
Age 55-59 & $83.3 \%$ & $82.8 \%$ & $69.3 \%$ \\
No qualifications & $65.9 \%$ & $64.2 \%$ & $50.0 \%$ \\
School qualifications & $57.2 \%$ & $52.0 \%$ & $63.9 \%$ \\
Post-school qualifications & $64.1 \%$ & $57.7 \%$ & $76.5 \%$ \\
\hline
\end{tabular}

Source: Statistics New Zealand, Houschold Labour Force Sun'ey.

Note. Table Four shows September 1991 levels, even though, as is evident from Graph Seven. this was not the period of lowest participation rates. The aggregate participation rate was actually lowest in the March 1993 quarter.

It is also puzzling that hours worked declined only slightly between 1989 and 1992, when demand-related wages rose significantly.

\section{Summary}

The pattern of slowdown in the late 1980 s, followed by recovery in the early 1990s is evident for almost all of the series considered. The variation across subgroups in this general pattern is significant, and suggests that a simple cyclical story is inadequate. The robustness of part-time employment, female employment, employment in the service industries, and employment of highly qualified workers suggests that we need to look beyond the cyclical story for an explanation. Similarly, the relatively poor outcomes that have persisted for Maori and Pacific Islands peoples, young workers, and those with no qualifications, and the failure of unemployment rates to return to earlier levels cannot be explained by cyclical effects alone.

The explanations may lie in longer term trends that have counteracted the effects of the slowdown or of the recovery: in different rates of adjustment for different groups or different variables; in changes that have been experienced by other developed countries, or in changes in the levels or growth rates of labour market measures as a consequence of the reforms and restructuring that have taken place. The following section outlines some of the other factors that researchers need to consider.

\section{Some possible explanations}

The paper so far has been largely descriptive. This has been intentional for two reasons. First, a clear understanding of the nature of the changes that have taken place provides a much sounder basis for informed debate and research. Second, to go further would require much more extensive research, or incautious speculation. As noted earlier, it is a far from trivial task to separate the many factors that have influenced the outcomes that we observe. In this section, I will look beyond the cyclical pattern that I have already presented, and outline briefly some of the other factors that researchers need (1) consider.

\section{Economic cycles and the effects of reform}

The slowdown in the New Zealand economy and labour market in the late 1980s had many of the features of a very large business cycle recession. The timing of the downturn in the mid-to late 1980 s was, however, unusual. The New Zealand economy is historically fairly sensitive to international growth trends, but it appeared to "break step" during the 1980s and 1990s. As noted by the OECD,

" ... the New Zealand economy broadly stagnated in the second half of the 1980s, when other countries enjoyed strong growth, and then entered recession, in parallel with the international business cycle ... rapid growth in recent yeirs represents to a considerable degree a cyclical rebound, underpinned by business and household spending which was deferred during the recession." 14

The stagnation of the late 1980 s is generally associated with the major programme of reforms that was undertaken in New Zealand, beginning in 1984. The OECD, in its 1994 country report on New Zealand, attributed the slow growth of the late 1980s to the fact that "the New Zealand economy proved slow to respond to the broadly-based structural reform progrimme pursued since 1984."15 


\section{Graph 8. Unit labour costs and real wages}

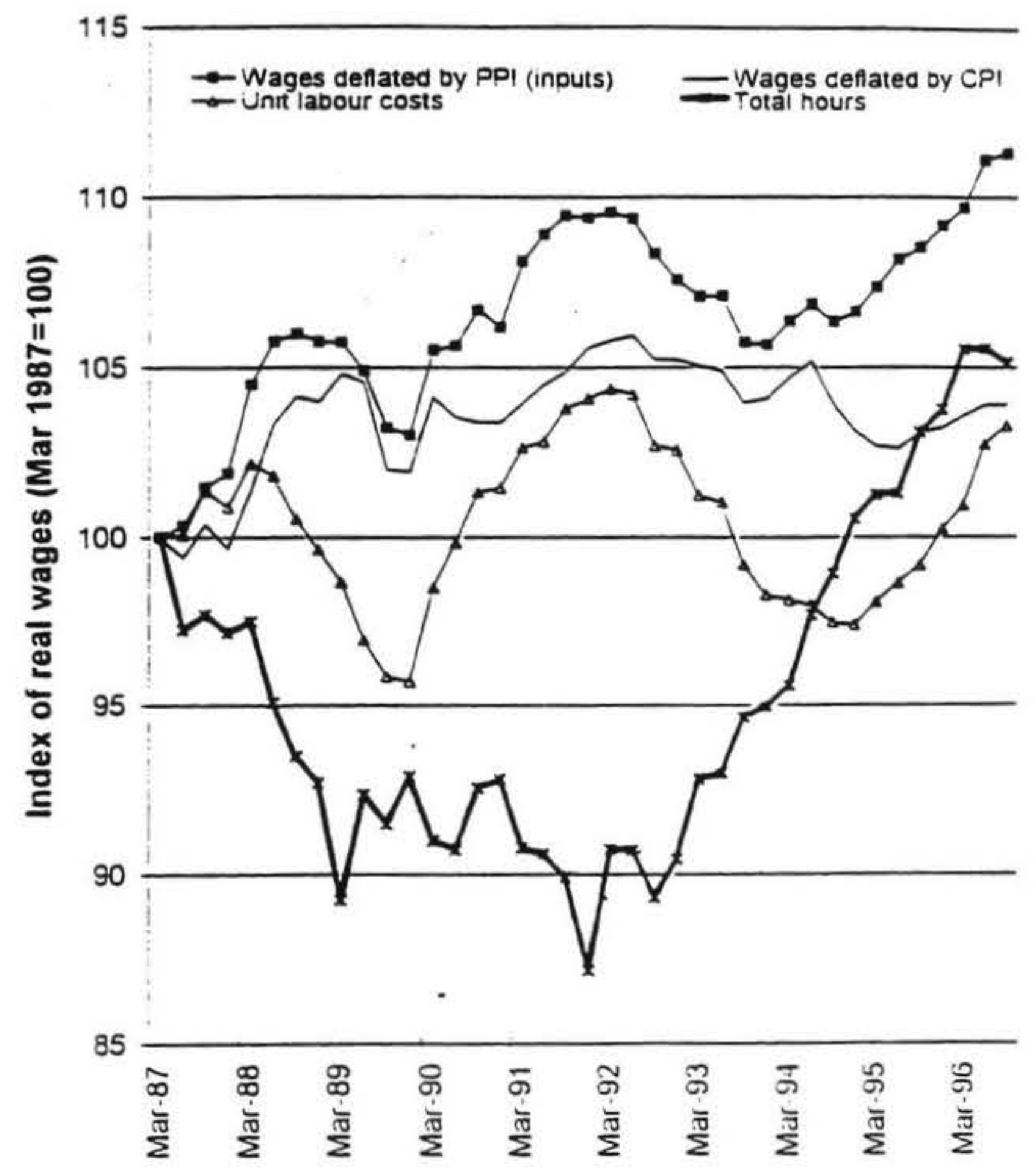

Source: Statistics New Zealand. All wage measures are based on Quarterly Employment Survey Average Hourly Earnings. The Unit Labour Cost is calculated by dividing the wage level by the Producer Price Index (Outputs), and then dividing the resulting quantity by productivity (measured a.s seasonally adjusted real GDP(production) divided by QES aggregate hours worked.) The Total Hours data are from the QES. All series are indexed to equal 100 in March 1987.

The labour market changes that we would expect from the reforms were in some ways similar to those that are normally observed as cyclical variations. Industries such as manufacturing, which tend to vary with aggregate activity levels, were also affected by the reforms. The pattern of employment declines in manufacturing industries, and for full-time, Maori, youth, and low-skilled workers were similarly affected by both the reforms and cyclical effects.

Although it is difficult to separate the different sources of labour market changes, any analysis of current trends must contain some judgements about the source of changes. Where changes have been the result of structural or policy changes, we would not necessarily expect measures to return to their prior levels or rates of growth. The employment losses in manufacturing industries, for instance, need not be regained in manufacturing - workers may instead he employed, and resources used, in other industries. Similarly, public sector employment, which is not highly cyclical, declined as a result of deliberate reforms. The decline in public sector employment has continued throughout the $1986-96$ decade, and is currently about 80,000 jobs lower $^{16}$ than it was in 1987.

Where changes have not been solely cyclical, we would expect in the long run some parts of the labour market to more than regain their previous levels or growth paths, and other parts to less than regain their earlier positions.

\section{Long-term trends}

Another possible reason that we might expect to see less (or more) than a complete reversal of the changes observed in the 1986-91 period, is that long term trends that were occurring prior to 1986 have continued. For instance, a rising share of employment accounted for by service industries has been a feature of the New Zealand labour market (and that of other developed countries) for many years. This trend shows up in the employment changes presented in Table Two. Service industry employment growth was positive when overall employment dropped, and was stronger than average when overall employment recovered. ${ }^{17}$

Other trends that need to be considered when examining recent or projected labour market trends include demographic changes, changes in education and training levels, trends in participation rates, and changes in technology and workplace organisation. All of these changes are discussed in more detail in various papers at the Seventh Labour Employment and Work Conference. I will therefore restrict the discussion to some fairly general statements.

For a start, demographic factors should never be ignored. The changing age structure of the population is a strong 
determinant of labour supply, and will show up to some degree in any analysis of the labour market performance of specific age groups. It is also relevant when different groups have different demographic profiles. For instance, the Maori working age population is, on average, younger than the population as a whole, and the labour market performance of Maori reflects this fact.

Graph Nine gives a broad picture of changes in the age structure of the working age population over the past decade. Different age groups are growing at different rates, and the graph shows the shares of total working age population that are accounted for by the different groups. The share of the 30 to 44 year old age group has been increasing steadily over the decade, as the baby-boomers enter this group. It is also evident that the share of the 45 to 59 year old group started increasing in about 1990, which is 45 years after the end of World War Two and the start of the baby boom.

The pattern of population changes must be taken into account when interpreting age-specific employment growth rates as are shown in Table Two. The decline in employment for 15 to 19 year olds, and for 20 to 24 year olds, is at least partly accounted for by the declining numbers of 15 to 24 year olds. ${ }^{18}$

Table Five shows long term trends in participation rates, industry structure, and the importance of part-time employ- ment. The trends shown in the table are not restricted to New Zealand - similar trends are evident for almost all developed economies. We have already seen the effect of these long term trends in the discussions of recent changes in the New Zealand labour force. Recall that female participation, parttime employment, and service industry employment all rose slightly between 1986 and 1991 , at a time when most other employment and participation rate measures were declining. It would appear that the effects of the longer term trends were just sufticient to offset the other changes that were occurring.

The trend rise in part-time employment is not the only feature of employment arrangements that has been changing. It is, however, one of the best documented. Other changes in the nature of work include changes to flexible hours arrangements, changes in job tumover rates, multiple joh holding, and job-sharing. There is a mix of anecdotal and statistical evidence that the nature of work in New Zealand is changing, although the lack of reliable long-term data makes it difficult to determine whether the observed changes in recent years are a result of longer term or international changes, or whether they are associated with changes in the New Zealand economic and labour market structure and institutions.

Workplace reform can be seen in a similar context. It is clear that there have been many new initiatives in the way that

\section{Graph 9 Changes in age structure}

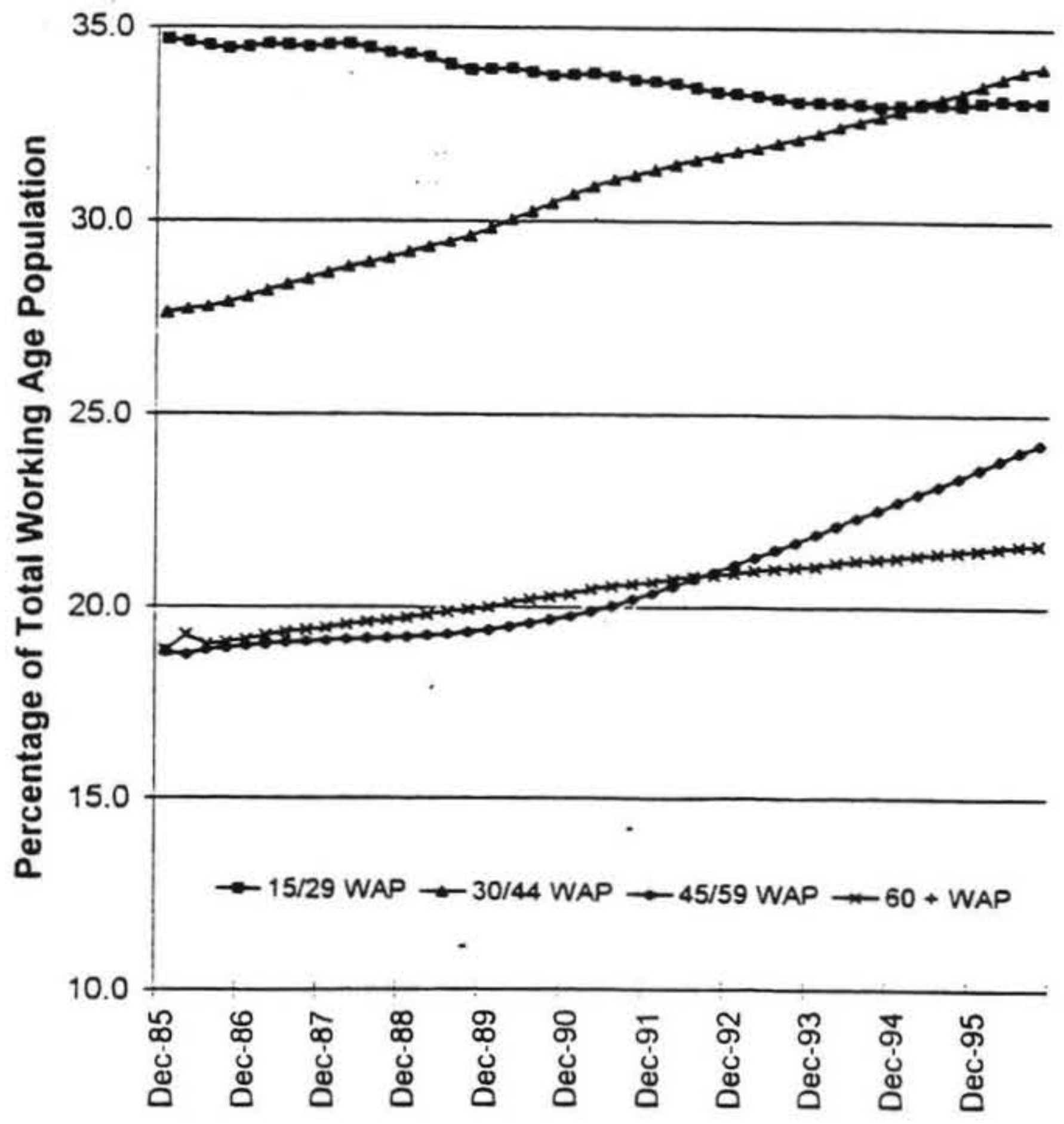

Source: Statistics New Zealand, Household Labour Force Survey. 
Table 5.Long-term trendsin participation rates, industry composition, and full-time/ part-time employment

1961

1991

percentage

point

change

\section{Participation rate by gender}

$\begin{array}{llll}\text { Male } & 83.3 \% & 68.6 \% & -14.7 \\ \text { Female } & 25.0 \% & 44.7 \% & 19.7\end{array}$

Share of employment by sector

(excluding primary industries)

$\begin{array}{llll}\text { Manufacturing } & 33.8 \% & 19.2 \% & -14.5 \\ \text { Services } & 55.0 \% & 72.9 \% & 17.9 \\ \text { Other } & 11.2 \% & 7.8 \% & -3.4\end{array}$

Share of employment (full-time/part-time)

$\begin{array}{llll}\text { Full-time } & 95.2 \% & 82.2 \% & -13.0 \\ \text { Part-time } & 4.8 \% & 17.8 \% & 13.0\end{array}$

Source: Statistics New Zealand. Participation data are based on census data obtained from Statistics New Zealand (1993). Sectoral Employment data are from Half-yearly Survey of Employment for 1961, and from the Quarterly Employment Survey for 1991. Parttime and full-time employment data are taken from censuseses.

New Zealand workplaces organise work. It is more diflicult to judge whether these are part of a longer term trend, a reflection of world-wide changes, or a response to current and recent conditions.

International changes in labour market behaviour do show up in New Zealand data to varying degrees. Two international changes that have received particular attention over the past decade have been the slowdown in productivity growth, and the changing wage premium paid to skilled workers.

The OECD (1996) reports that growth in output per hour worked in the seven largest OECD economies halved during the 1970 s to about two percent. It then remained relatively constant through the 1980s before falling again in the early 1990s. Any discussion of New Zealand's productivity performance must be seen in the context of these developments.

International research has also highlighted an increase in average qualifications, and also in the premium paid for skilled labour, which occurred in the 1980s in a number of OECD countries. Graph Ten shows the relative employment shares and relative wages for two different skill groups - those with no qualifications, and those with post-school qualifications. ${ }^{19}$

The increase in qualifications levels of employees is clearly evident. The share of employees accounted for by workers with post-school qualifications rose by around ten percentage points, and the share of employees with no formal qualifications fell by over fifteen percentage points. The rising wage premium for qualifications that has been ob- served overseas does not, however, appear to have occurred in New Zealand. The (raw) wage premium for workers with post-school qualifications declined, as did the relative wages for those with no school qualifications. This pattern suggests that supply increases for highly-qualified workers, and decreases in the share of the labour force with no qualifications has more than compensated for any increase in the relative demand for more skilled workers.

The relatively poor employment and unemployment outcomes for less qualified workers that is evident in Tables Two, Three and Four should be interpreted with these changes in mind.

These, and other, long term trends are almost certainly related. For instance, the rise in the Service sector and the rise in part-time employment are related, in that part-time employment is more common in service than in other industries. Similarly, female participation has been associated with the increased employment opportunities for part-time and service industry jobs, which account for a disproportionately large share of female employment.

\section{Labour market policy changes?}

We have already discussed the importance of the major reforms and policy changes that started in the mid-1980s. These undeniably played a large part in labour market performance in the past decade. There have also been policy changes that have more directly affected the labour market, including the introduction of the Employment Contracts Act (ECA), and changes to active labour market policy measures.

Given the broad pattern of changes that have been discussed in this paper, it is obviously difficult to separate out the effects of any single policy reform. The ECA, for instance, was enacted in 1991, which was about the time that output and employment began to recover. Although we would expect the EC.A to have had positive effects on economic and labour market performance, it would be unwise to attribute the strength of the 1991 to 1996 recovery solely to this piece of legislation.

Similarly, changes in active labour market policies that were introduced in response to the recommendations of the Employment Task Force were designed to reduce long-term unemployment, increase participation, and generate better outcumes for those who were disadvantaged in the labour market. Labour market outcomes in recent years have shown progress in all three of these areas. Looking at these results in a broader context suggests that the policy changes reinforced changes that were already occurring, but were not the sole source of those changes.

\section{The outlook}

Sustainable growth in both employment and real wages must be underpinned by growth in the labour force and growth in productivity. Growth in productivity alone will lead to higher real wages and output for any given level of labour 


\section{Graph 10 Relative employment shares and wages}

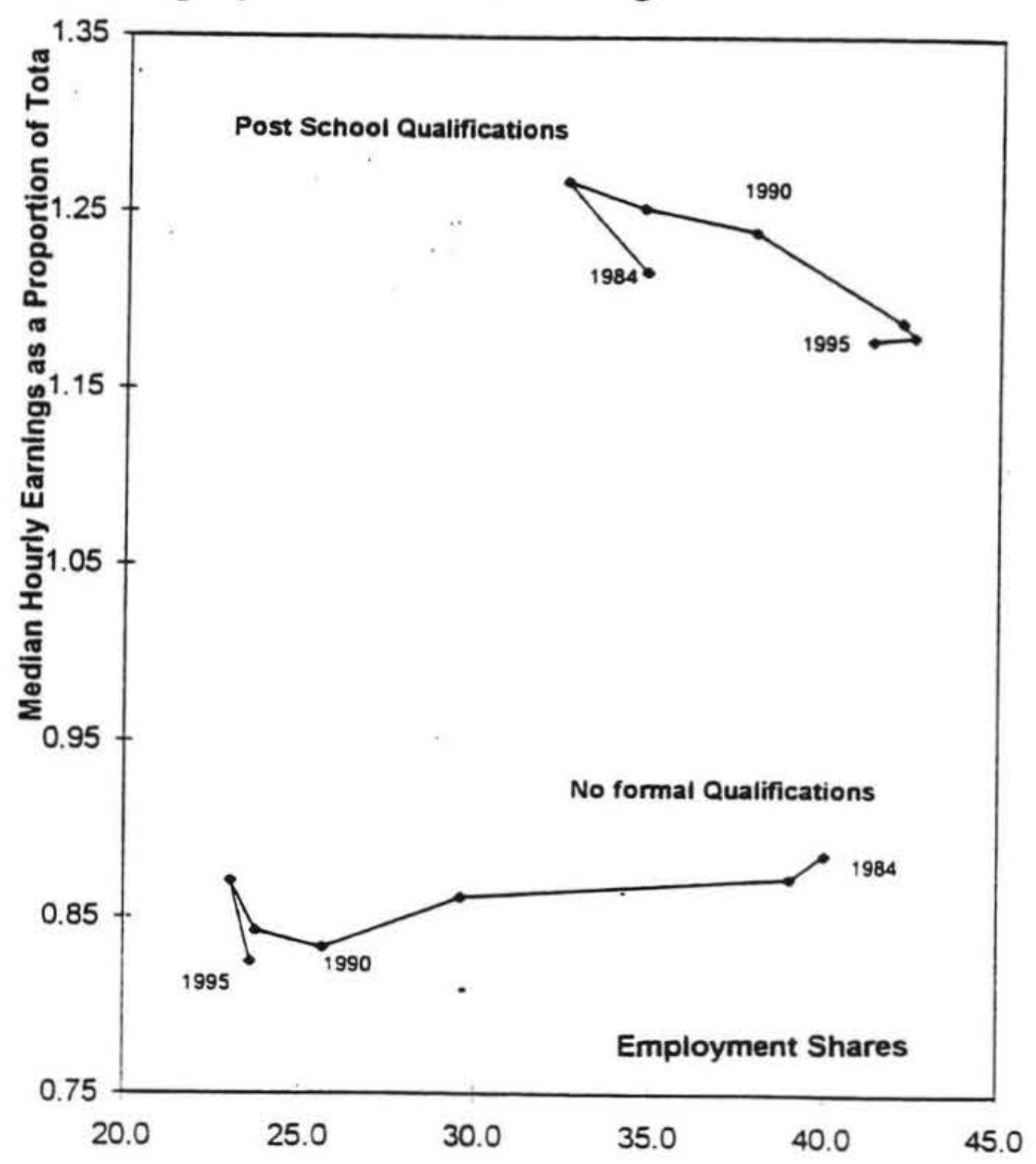

Source: Statistics New Zealand Household Economic Survey Data, and Department of Labour Calculations. See Dixon (1996) in this volume for details.

input. If this is accompanied by growth in the labour input, through a rise in hours worked, participation, natural increase, or migration, employment can be increased, albeit at the cost of slightly lower real wage growth. Without productivity growth, any increase in labour input will lead to higher levels of output, but at lower wage rates, or with inflationary effects.

Productivity growth is thus one of the most important influences on New Zealand's long run economic and labour market performance. This explains why so many of the reforms that have been introduced since 1984 have aimed to improve overall productivity, through better allocation of resources, and greater responsiveness to market opportunities. It also explains the high degree of interest in current productivity performance.

New Zealand's historical rate of productivity growth has been poor. Between 1960 and 1987, average real GDP per person employed grew at 1.4 percent per annum, compared with an OECD average of 2.6 percent per annum. During the 1980 s, New Zealand's productivity growth was slightly above the OECD average. ${ }^{20}$ In the 1990 s, New Zealand productivity growth has been relatively low, although this period includes the negative impact of the current growth slow-down. 21

It is difficult to conclude how New Zealand's long-run productivity growth has been changed by the developments of the last decade, partly because those developments are still working through. It is only when we can see what the trend growth rates for output and employment are that we will be able to tell whether productivity growth has been raised.

There is a little more agreement on the outlook for the next two years. The New Zealand Institute of Economic Research (NZIER) compile an average of the forecasts of a number of forecasting agencies, and publish the results as a "consensus forecast. Table Six shows the consensus forecasts based on forecasts available in September 1996.

The outlook for the economy and for the labour market is reasonably positive. Output and employment growth are expected to slow, but to remain positive in the three years to March 1999. Unemployment, however, is not expected to rise slightly between now and March 1997, and to decline only slightly in the following two years. The growth in employment is forecast to be just sufficient to absorb the increase in lahour supply.

Wage growth is expected to stay at about current levels until March 1997, and then to slow slightly over the next two years.

\section{Conclusions}

This paper has provided a context in which to consider recent

Labour, Employment and Work in New Zealand 1996 
labour market trends and the outlook for the New Zealand labour market. The past ten years have seen a period of relatively poor labour market outcomes, followed by a period in which much of the ground was regained. Some measures have returned to their 1986 levels, while others are now higher or lower than they were. Part of the explanation for sustained differences lies in the existence of longer term trends, although there are still many questions about whether some of the changes are a result of the reforms and policy changes of the past decade, or of other changes that are affecting other countries as well. It is also likely that some of the observed differences between now and 1986 are due to the fact that the process of major adjustment that New Zealand has experienced is not yet over, and that it will be some years before new growth paths and patterns are evident.

Given the range of influences on the labour market over the past decade, it is probably safe to say that any simple stories to explain current trends are probably too simple. It is also) safe to say that extrapolation of changes observed in the past five years, or over the past decade, are likely to be misleading.

Personally, I am optimistic about the prospects for the labour market - although not as optimistic as some. I think that there is still some way to go before the process of adjustment is over and we are able to gauge accurately the underlying trends in output, employment, and productivity. The consensus forecasts indicate that forecasters expect fairly slow and steady change in output, employment and wages, and a very slow rate of reduction in unemployment. Time will tell whether the labour market will behave this smoothly, or whether the future will throw up more surprises to entertain and puzzle labour researchers.

\section{Future research}

Not surprisingly given the breadth of topics covered in this article, we have touched on a large number of areas where research could make a valuable contribution to our under- standing of the New Zealand labour market. Although we have described the patterns of output, employment, unemployment, participation, productivity, and wages, there is still considerable work needed to gain a full understanding of the trends and patterns that we observe.

Perhaps the most general research question that has been identified is whether there has been a long term change in the structure of the labour market or in the way that the labour market operates. This paper has identified a range of influences and factors that a researcher would need to consider and control for before being able to answer this question. One of the strong messages is the importance of looking at changes over a fairly long period, in order to allow for the pattern of partial reversal that characterises many of the series over the past ten years. This is especially important, and problematic, given that some of the regulatory changes in the labour market occurred at around the same time as the upturn in economic activity. Although it is too soon to ohserve any structural changes clearly in simple time series graphs, it may be possible to isolate changes in underlying relationships through well-designed research work.

There are some factors that have not been addressed at all in this paper, and which would be fertile grounds for further research. In particular, the paper has not considered the extent and causes of regional variation in labour market performance. Such analysis would provide a richer and fuller understanding of recent labour market dynamics.

\section{Notes}

1. Bollard \& Buckle (1987), Silverstone, Bollard \& Lattimore (1996).

2. During 1993 and 1995 , annual full-time employment growth was faster than annual part-time employment growth for several quarters.

3. The choice of period is constrained by the availability of

Table 6. NZIER Consensus forecasts

\begin{tabular}{lccc}
\hline Variable & March 1997 & March 1998 & March 1999 \\
\hline Output growth (aapc) & $\begin{array}{l}1.8 \\
(1.5-2.5)\end{array}$ & $\begin{array}{c}3.2 \\
(2.2-4.1)\end{array}$ & $\begin{array}{c}2.8 \\
(1.4-3.5)\end{array}$ \\
Employment Growth (aapc) & 1.7 & 1.7 & 1.7 \\
& $(0.8-2.6)$ & $(0.4-2.5)$ & $(0.5-2.4)$ \\
Implied productivity growth & 0.1 & 1.5 & 1.1 \\
Unemployment Rate (\%) & 6.6 & 6.4 & 6.4 \\
& $(6.2-7.5)$ & $(5.6-7.9)$ & $(5.7-7.5)$ \\
Private Sector Hourly Wages (aapc) & 3.1 & 2.6 & 2.6 \\
& $(1.8-3.9)$ & $(1.2-4.5)$ & $(1.6-3.0)$ \\
\hline
\end{tabular}

Source: NZIER Consensus Forecasts. The numbers in brackets indicate the range of forecasts. 
consistent data series. Ideally, we should take as our points of comparison two periods that are at about the same stage in the economic cycle. It would also be preferable to use a period that coincides with the introduction of the extensive reforms referred to in the introduction. Unfortunately, the Household Labour Force Survey did not start until the December quarter of 1985 , and the first September quarter data are therefore for the 1986 year.

4. The data are displayed as indexes, showing the levels of output and employment relative to their level in March 1986.

5. The growth is measured as an annual average percentage change, which is averaged across the relevant quarters.

6. Continuing to produce the same level of output with lower employment represents an increase in average labour productivity. Labour productivity trends will be discussed in more detail later in the paper.

7. Due to the relatively small sample size, HLFS estimates of Pacific Islands peoples' labour market measures are very volatile.

8. Using an employment measure generally gives slightly slower estimated productivity growth because of the slightly growing proportion of employment that is part-time. In some recent periods, declines in average full-time hours have generated the opposite pattern.

9. Due to the relatively small sample size, HLFS estimates of Pacific Islands peoples' labour market measures are very volatile.

10. Prime Ministerial Task Force on Employment (1994), p. 18.

11. Gross flows data are also available from the Household Labour Force Survey, but on quarterly basis, and only since 1986.

12. Due to the relatively small sample size, HLFS estimates of Pacific Islands peoples' labour market measures are very volatile.

13. Unit labour costs appear lower on the graph only because of the index period that was chosen.

14. OECD (1996b), OECD Economic Surveys, New Zealand, $\mathrm{p} 3$.

15. OECD (1994), OECD Economic Surveys, New Zealand, p. 11.

16. Data used are from the Quarterly Employment Survey.

17. Over the past three years, this statement does not hold overall employment growth has been slightly faster than services industry growth.

18. This decline in the number of 15 to 24 year olds appears in Graph Nine as a declining share. The decline in population numbers is not the only cause - increased educational participation also contributes to the decline in teenage and young adult employment.

19. The graph is based on estimates from Dixon (1996).

20. Savage, J., (1989), and OECD (1996), Vol 2: Analytical Report, p. 44

21 . When growth slows down, there is generally a lag before employment growth slows, and this lag generates a period of negative productivity change.

\section{References}

Bollard, A.E. and Buckle R.A. 1987, Economic Liberalisation in New Zealand. Allan and Unwin.

Dixon. S. 1996, Changes in the Earnings Distribution beween 1954 and 1995, Paper given at the Seventh Labour Employment and Work Conference, Victoria University.

New Zealand Institute of Economic Research, Consensus Forecasts, September 1996.

OECD 1996a, Technology, productivity and job creation, Vol 2: Analytical Report.

OECD 1996b, OECD Economic Surveys, New Zealand.

OECD 1984. OECD Economic Surveys, New Zealand.

Prime Ministerial Task Force on Employment 1994, Employment, The Issues.

Savage J. 1989, New Zealand's productivity performance: an international comparison, New Zealand Institute of Economic Research, Working Paper No. $89 / 29$.

Silverstone B., Bollard A.E. and Lattimore R. 1996, A Study of Economic Reform: The Case of New Zealand. North Holland.

Statistics New Zealand (1993), New Zealand Social Trends: Work

\section{Author}

Dave Maré is the Manager of Research and Monitoring in the Labour Market Policy Group of the Department of Labour. 